\title{
A Study On Customer Perception Towards Services Of Selected Public And Private Sector Banks -With Special Reference To Coimbatore City
}

\author{
*Ms.K.Sumathi, **Dr. M.Thyagarajan \\ 1. (Assistant Professor in Commerce, Dr.SNS Rajalakshmi College of Arts and Science/Bharathiar University, India) \\ 2. (Associate Professor in Commerce, Dr.SNS Rajalakshmi College of Arts and science/Bharathiar University, India)
}

\begin{abstract}
Banking system occupies an important place in a nation's economy. A banking institution is indispensable in a modern society. It plays a pivotal role in the economic development of a country and forms the core of the money market in an advanced country. The phenomenon of globalization brought about significant changes in terms of products and services that are being offered to Indian customers and consequently the complexion of the banking sector in India too underwent a note worthy change in the last decade. In this content the study is taken up the services provided by the public and private sector banks. This paper reveals the customer perception towards services of selected public and private sector banks in Coimbatore city and it also helps to analyze the improvement in the banking services. Various tools used to analyse the data. The present study helps the banker to educate their customer by providing various services based on technological development to the satisfaction of their customer.
\end{abstract}

Key word: Customer Awareness, Expectations, Maintenance, Services, Selection of the Bank

\section{INTRODUCTION}

Banking system occupies an important place in a nation's economy. A banking institution is indispensable in a modern society. It plays a pivotal role in the economic development of a country and forms the core of the money market in an advanced country. The phenomenon of globalization brought about significant changes in terms of products and services that are being offered to Indian customers and consequently the complexion of the banking sector in India too underwent a note worthy change in the last decade. The emergence of new private sector and foreign banks is one of the major challenges before the public sector commercial banks in India and this prompted the Indian banking industry to reckon with the challenges posed by the competition while rendering services to the customers.

\section{STATEMENT OF PROBLEM}

Banking industry has started to occupy an important place in the life of different types of people including a common man. It is no longer considered as a luxury. It has become a necessity. In our country, banking service is provided by the public sector banks, as well as co-operative, private and foreign sector Banks. The Reserve Bank of India regulates the banking service industry. The customers in addition to the public sector banks increasingly prefer private sector and foreign sector service providers.

Though all the Commercial Banks are providing Value-added services, enquiries on Banks customers have been made on the following.

$>$ What are the services provided by the banks?

$>$ How far the services cater to the needs of the customers?

$>$ To what extent the services are utilized by the customers?

$>$ What are the problems faced by the customers?

$>$

\section{OBJECTIVE OF THE STUDY}

1. To study the different services provided by the bank to the customers

2. To examine the expectations and the level of satisfaction of the customers towards the services

3. rendered by Public and Private sector banks

4. To identify the areas which need improvement, so that the service of these banks is enhanced.

\section{HYPOTHESIS OF THE STUDY}

1. There is no significant relationship between gender and overall satisfaction of the respondent.

2. There is no significant relationship between age and overall satisfaction of the respondents.

3. There is no significant relationship between occupational status and overall satisfaction of the respondents.

4. 


\subsection{Data Collections}

The study is based on questionnaire method;

$>$ Primary data were collected from respondents.

$>$ Secondary data were collected from books, journals, magazines and websites.

\subsection{SAMPLING}

A Sample of 300 customers has been selected for the study using the convenient sampling method.

\subsection{FRAMEWORK OF ANALYSIS}

- Simple percentage Analysis,

- Chi-Square test,

- Garrett Ranking techniques,

- Reliability analysis,

- Discriminate Analysis.

\section{SIMPLE PERCENTAGE ANALYSIS}

\section{ANALYSIS AND INTERPRETATION} TABLE 1 GENDER OF THE RESPONDENTS

\begin{tabular}{|c|c|c|c|c|c|}
\hline S.NO. & Gender & Mean & S.D & No. of Respondents & Percentage \\
\hline 1 & Male & 1.99 & .919 & 160 & 53.3 \\
\hline 2 & Female & 2.31 & .849 & 140 & 46.7 \\
\hline & Total & 2.16 & .900 & 300 & 100 \\
\hline
\end{tabular}

Source: Primary Data

It is clear from the above table 53.3 per cent of the respondents are male with mean and standard deviation of 2.31 and .919 and 46 per cent of them are female with mean and standard deviation of 1.99 and 0.849. Majority of the respondents are male with the mean score of 2.31 .

TABLE- 2 CHOICE OF THE BANK

\begin{tabular}{|c|c|c|c|c|c|}
\hline S.NO. & $\begin{array}{c}\text { In which bank do you have } \\
\text { A/c }\end{array}$ & Mean & S.D & No. Of Respondents & Percentage \\
\hline 1 & Public bank & 2.08 & .903 & 220 & 73.3 \\
\hline 2 & Private bank & 2.38 & .862 & 80 & 26.7 \\
\hline & Total & 2.16 & .900 & 300 & 100.0 \\
\hline
\end{tabular}

Source: Primary Data

From the above table 73.3 per cent of the respondents have their bank dealing in public banks and only 26.7 per cent of them have dealing in private banks. Majority deals with public banks because of safety purpose.

TABLE- 3 DETAILS OF MAINTAING THE BANK ACCOUNT

\begin{tabular}{|c|l|c|c|c|c|}
\hline S.NO. & $\begin{array}{l}\text { How long are you } \\
\text { maintaining your A/c }\end{array}$ & Mean & S.D & No Of Respondents & Percentage \\
\hline 1 & Less than 1 year & 2.75 & .439 & 40 & 13.3 \\
\hline 2 & 1-5 year & 2.04 & .914 & 180 & 60 \\
\hline 3 & 5-10 year & 1.60 & .808 & 50 & 16.7 \\
\hline 4 & Above 10 year & 3.00 & .000 & 30 & 10 \\
\hline & Total & 2.16 & .900 & 300 & 100 \\
\hline
\end{tabular}

Source: Primary Data

It is clear from the above table 60 per cent of the respondents have maintained their a/c with 1-5 years. 16.7 per cent of them deal with 5-10 years .13.3 per cent of the respondents deals with less than 1 year and 10 per cent of them have above 10 years. Majority of the respondents do operate their account with the period of 15 years. 
Chi-Square Analysis

Table - 4

Overall Chi-Square Analysis Between Personal Factors And Overall Satisfaction

\begin{tabular}{|c|c|c|c|c|c|}
\hline \multirow{2}{*}{ S.NO } & \multirow{2}{*}{ PERSONAL FACTORS } & \multicolumn{4}{|c|}{ LEVEL OF SATISFACTION } \\
\hline & & \multirow{2}{*}{ VALUE } & \multirow{2}{*}{$D f$} & \multirow{2}{*}{ p-Value } & \multirow{2}{*}{ S/NS } \\
\hline 1 & GENDER & & & & \\
\hline & Pearson Chi-Square & 34.285 & 2 & $0.000 * *$ & $S$ \\
\hline & Likelihood ratio & 35.764 & 2 & 0.000 & \\
\hline & Linear-by-Linear Association & 9.839 & 1 & .002 & \\
\hline & No. of Valid Cases & 300 & & & \\
\hline \multirow[t]{5}{*}{2} & $A G E$ & & & & \\
\hline & Pearson Chi-Square & 88.459 & 8 & $0.000 * *$ & $S$ \\
\hline & Likelihood ratio & 115.081 & 8 & .000 & \\
\hline & Linear-by-Linear Association & 56.984 & 1 & .000 & \\
\hline & No of Valid Cases & 300 & & & \\
\hline \multirow[t]{5}{*}{3} & EDUCATIONAL LEVEL & & & & \\
\hline & Pearson Chi-Square & 154.088 & 8 & $0.000 * *$ & $S$ \\
\hline & Likelihood ratio & 154.696 & 8 & .000 & \\
\hline & Linear-by-Linear Association & 5.744 & 1 & .017 & \\
\hline & No. of Valid Cases & 300 & & & \\
\hline \multirow[t]{5}{*}{4} & OCCUPATIONAL STATUS & & & & \\
\hline & Pearson Chi-Square & 42.233 & 8 & $0.000 * *$ & $S$ \\
\hline & Likelihood ratio & 51.393 & 8 & .000 & \\
\hline & Linear-by-Linear Association & .740 & 1 & .390 & \\
\hline & No. of Valid Cases & 300 & & & \\
\hline \multirow[t]{5}{*}{5} & ANNUAL INCOME & & & & \\
\hline & Pearson Chi-Square & 60.796 & 6 & $0.000 * *$ & $S$ \\
\hline & Likelihood ratio & 72.250 & 6 & 0.000 & \\
\hline & Linear-by-Linear Association & 7.295 & 1 & 0.07 & \\
\hline & No. of Valid Cases & 300 & & & \\
\hline \multirow[t]{5}{*}{6} & MARITAL STATUS & & & & \\
\hline & Pearson Chi-Square & 58.403 & 2 & $0.000 * *$ & $S$ \\
\hline & Likelihood ratio & 59.240 & 2 & 0.000 & \\
\hline & Linear-by-Linear Association & 14.595 & 1 & 0.000 & \\
\hline & No. of Valid Cases & 300 & & & \\
\hline \multirow[t]{5}{*}{7} & AREA OF RESIDENCE & & & & \\
\hline & Pearson Chi-Square & 7.523 & 2 & $0.023 * *$ & $S$ \\
\hline & Likelihood ratio & 7.509 & 2 & 0.023 & \\
\hline & Linear-by-Linear Association & 4.061 & 1 & .044 & \\
\hline & No. of Valid Cases & 300 & & & \\
\hline
\end{tabular}

$S-$ Significant $\quad$ NS - Not Significant $* 5 \%$ level of significance $\quad * * 1 \%$ level of significance

TABLE - 5

Association Between Gender And Overall Satisfaction About Services

\begin{tabular}{|c|c|c|c|}
\hline \multicolumn{1}{|c|}{ Association Between Gender And Overall Satisfaction About Services } \\
\hline Particulars & Value & Df & P-value \\
\hline Pearson Chi-Square & 34.285 & 2 & $.000^{*}$ \\
\hline $\begin{array}{c}\text { Linelihood ratio } \\
\text { Association }\end{array}$ & 35.764 & 1 & .000 \\
\hline No. of Valid Cases & 9.839 & & .002 \\
\hline * Accepted Rejected
\end{tabular}

It's clear that the P-value is less than 0.05. The null hypothesis is rejected at 5\% level of significance. Hence there is significant relationship between gender of the respondents and overall satisfaction about service and also statistical significant. 
A Study On Customer Perception Towards Services Of Selected Public And Private Sector Banks -

Garrett Ranking Technique

Table-6 Reasons Behind Selecting The Bank

\begin{tabular}{|c|l|c|c|c|}
\hline \multicolumn{1}{|c|}{ FACTORS } & \multicolumn{1}{|c|}{$\begin{array}{c}\text { TOTAL } \\
\text { SCORE }\end{array}$} & $\begin{array}{c}\text { MEAN } \\
\text { SCORE }\end{array}$ & RANK \\
\hline 1 & Nearness & 1798.2 & 5.9 & $I$ \\
\hline 2 & Convenient Timing & 1651.9 & 5.5 & $I V$ \\
\hline 3 & Friendly staff & 1559 & 5.19 & $V$ \\
\hline 4 & Reputation of the bank & 1693.8 & 5.6 & III \\
\hline 5 & Prompt service & 1558 & 5.19 & VI \\
\hline 6 & Canvassing by the bank & 1102 & 3.6 & $X$ \\
\hline 7 & Dep of salary by the employee & 1411.5 & 4.7 & VII \\
\hline 8 & More loan facility & 1707.3 & 4.3 & VIII \\
\hline 9 & Fully computerization & 1254.1 & 5.8 & $I I$ \\
\hline 10 & Variety of other services & & 4.1 & IX \\
\hline
\end{tabular}

Source: Primary Data

The above tables reveals "Nearness" was ranked first by the selected sample respondents with the total score of 1798 and mean score of 5.9. Fully computerization was ranked second with the total score of 1757 and mean score of 5.8. Reputation of the bank and convenient timing occupied third and fourth position with the total score of 1694 and 1652 and mean score of5.6 and 5.5 respectively. Friendly staff was ranked fifth with the total score of 1559 and mean score of 5.19. Prompt service occupied sixth position with the total score of 1558 and mean score of 5.1. Deposit of salary by the employer and more loan facility occupies seventh and eighth position with the total score of 1412 and 1307 and mean score of 4.7 and 4.3 respectively. Variety of other services was ranked ninth with the total score of 1254 and mean score of 4.1. Canvassing by the bank occupied tenth position with the total score of 1102 and mean score of 3.6. It is evident that most of the respondents gave top priority to nearness as the first rank for selecting the bank.

\section{Reliability Analysis}

Table - 7 Reliability Of Scales And Item-Construct Loadings For Level Of Satisfaction In Order To Cope Up With The Behavior Of Bank Staff

\begin{tabular}{|c|l|c|c|}
\hline S.NO & \multicolumn{1}{|c|}{$\begin{array}{c}\text { STATISTICS REGARDING BEHAVIOR OF THE } \\
\text { BANK STAFF }\end{array}$} & $\begin{array}{c}\text { SCALE MEAN } \\
\text { IF ITEM } \\
\text { DELETED }\end{array}$ & $\begin{array}{c}\text { CRONBACH'S } \\
\text { DEPA IF ITEM } \\
\text { DELTED }\end{array}$ \\
\hline 1. & Courteous/Friendly people & 52.17 & .885 \\
\hline 2. & Availability of Answer to Question & 52.47 & .875 \\
\hline 3. & Explain things clearly \& Correctly & 52.27 & .880 \\
\hline 4. & Responsive to customers/needs/wants & 52.34 & .879 \\
\hline 5. & Accuracy in completing transaction & 52.30 & .890 \\
\hline 6. & Speed of Handling transaction & 52.40 & .886 \\
\hline 7. & Speed of the Services & 52.51 & .890 \\
\hline 8. & Knowledge of the employees & 52.47 & .898 \\
\hline 9. & Behavior of the bank staffs & 52.63 & .881 \\
\hline 10. & Courtesy of the Employees & 52.47 & .884 \\
\hline 11. & Sincerity in Problem Solving & 52.30 & .885 \\
\hline 12. & Promptness of the Services & 52.40 & .887 \\
\hline 13. & Individual Attention of the employees & 52.50 & .885 \\
\hline 14. & Reliability of the employees & 52.24 & .888 \\
\hline 15. & Understanding of your need & 52.36 & .886 \\
\hline & MEAN & & 61.726 \\
\hline & VARIANCE & & .89 \\
\hline & STD. DEVIATION & 15 \\
\hline & CRONBACH'S ALPHA & \\
\hline & NO OF ITEMS & & \\
\hline
\end{tabular}

Discriminent Function Analysis

Classification of Individual

Using the discriminate function fitted and the observed predictor variables of the companies, the companies are classified and the correct per cent of classification is presented below. 
A Study On Customer Perception Towards Services Of Selected Public And Private Sector Banks -

Table: 8 Percentage Of Correct Classification By Using Discriminate Function On The Data

\begin{tabular}{|c|c|c|c|c|}
\hline S.No. & Level of Satisfaction & High & Low & Total \\
\hline \multirow{2}{*}{1} & \multirow{2}{*}{ HIGH } & 121 & 30 & 151 \\
\cline { 3 - 5 } & \multirow{2}{*}{ LOW } & 80.1 & 19.9 & 100 \\
\hline \multirow{2}{*}{2} & & 30 & 119 & 149 \\
\cline { 3 - 5 } & & 20.1 & 79.9 & 100 \\
\hline
\end{tabular}

\section{SUGGESTIONS}

1) To strive, to attract and retain customer the bank has to introduce innovative products, enhancing the customer services and marketing through different channels targeted at specific customer.

2) Proper technical training to staff must be provided to handle crisis situation

3) Bank should create awareness in rural areas regarding their new schemes and should train and educate if necessary.

\section{CONCLUSION}

In the new environment the bank has to sell its product with a view to maximize the profit and to attract the customers with better services. The bankers have to realize the implication of market economy and adjust accordingly. The bank has to equip itself to meet the challenges of tomorrow banking. The present study helps the banker to educate their customer by providing various services based on technological development to the satisfaction of their customer.

\section{BOOKS}

\section{BIBLIOGRAPHY}

[1] R.K.Uppal, Customer Relationship Management in Indian Banking Industry( New Century Publications ,New Delhi ,Ed -2008).

[2] Varshney, Banking theory law and practice( Sultan Chand \& Sons Company Ltd, New Delhi 1997).

[3] Dr.S.P.Gupta, Statistical Methods( Sultan Chand \& Sons Educational Publishers, New Delhi-2006).

[4] S.N Natrajan\&R. Prameswaran ,Indian banking (S. Chand 2006 ).

[5] C.R. Kothari,Research Methodology Methods and Techniques(New Age International (P) Ltd, Publishing, New Delhi Ed-2004 ).

[6] Dr.Vashisth B.P.V.K Dr H.R.Swami, Banking and Finance( Ramesh book Depot, jaipur-New Delhi 2005-2006).

\section{JOURNALS}

[7] The journal of Banking Studies, Bankers College New Delhi, April 2004, p.22.

[8] The ICFAI journal of marketing management, August 2006,vol.v, No.3

[9] Bank quest - Journal of Indian Institute of Banking \& Finance Mumbai -5 July Sep 2004 p.59.

[10] Bank quest -Journal of Indian Institute of Banking \& Finance Mumbai - 05 Jan - Mar 2005 p-61.

[11] Oriental Bank of commerce Watch, Vigilance Department on Behalf of OBC - National printers, New Delhi-8.

[12] Indian Bankers Associations Bulletin.

[13] Monetary and Credit Information Review-RBI Mumbai, Dec2006.

\section{WEBSITE}

www.google.com. www.informationweek.com.

www.cir.rbi.org.in

www.yahoo.com 